\title{
Effect of Beta Glucosidase Inhibitor from Lichen Extract in Microcrystalline Cellulose Preparation from Water Hyacinth (Eichhornia crassipes)
}

\author{
Citra Bonnita Putri ${ }^{1}$, Sutriyo ${ }^{2}$, Herman Suryadi ${ }^{1, *}$
}

Citra Bonnita Putri', Sutriyo², Herman Suryadi ${ }^{1, *}$

'Laboratory of Microbiology and

Biotechnology, Faculty of Pharmacy,

Universitas Indonesia, Depok 16424, INDONESIA.

${ }^{2}$ Laboratory of Pharmaceutical Technology, Faculty of Pharmacy, Universitas Indonesia, Depok 16424, INDONESIA.

\section{Correspondence}

Herman Suryadi

Laboratory of Microbiology and

Biotechnology, Faculty of Pharmacy,

Universitas Indonesia, Depok 16424

INDONESIA.

E-mail: hsuryadi@farmasi.ui.ac.id

History

- Submission Date: 10-02-2019;

- Review completed: 12-04-2019;

- Accepted Date: 24-05-2019.

DOI : 10.5530/pj.2019.11.186

Article Available online

http://www.phcogj.com/v11/i6

Copyright

(C) 2019 Phcogj.Com. This is an openaccess article distributed under the terms of the Creative Commons Attribution 4.0 International license.

\begin{abstract}
Objective: Microcrystalline cellulose (MCC) is an excipient commonly used in the manufacturing of pharmaceutical preparations, especially tablet. MCC has been successfully made from water hyacinth (Eichhornia crassipes) through enzymatic hydrolysis process. This study aimed to find the effect of $\beta$-glucosidase inhibitor from lichen extract to the yield of MCC, the optimum conditions of enzymatic hydrolysis including $\mathrm{pH}$ and reaction time and characteristics of MCC obtained compared to reference, Avicel PH-101. Method:The study was began with extraction of cellulose enzyme and followed by determination of optimum beta-glucosidase inhibitor concentration. Then, this conditions were used for enzymatic hydrolysis of $\alpha$-cellulose to MCC, followed by identification and characterization of MCC obtained and compared with Avicel PH101. Results: The optimum concentration of inhibitor was 120 ppm. A little higher yield of MCC was obtained when inhibitor extract is used in hydrolysis alfa-cellulose to MCC. The identity of MCC obtained was similar to infrared spectrum of reference. Other characteristics of MCC obtained were powder in the form of a slightly coarse, odorless and tasteless and slightly yellowish than reference. Conclusion: Addition of extract of Beta glucosidase inhibitor did not improve the MCC yield significantly, but identity and characteristics of MCC obtained showed similarities to the microcrystalline cellulose reference (Avicel PH = 101).
\end{abstract}

Key words: $\beta$-glucosidase inhibitor, Enzymatic hydrolysis, Lichen extract, Microcrystalline cellulose, Water hyacinth.

\section{INTRODUCTION}

Cellulose is the most abundant organic polymer in nature which can be hydrolyzed to glucose by microbial enzymes. Water hyacinth has a relatively high cellulose content, which is up to $60 \% .^{1}$ This makes water hyacinth potentially useful as a new cellulose source.

One form of cellulose is microcrystalline cellulose (MCC). MCC is widely used in the pharmaceutical industry as a tablet filling material. Based on the research that has been carried out, cellulose derived from the stem can be a source of MCC and has relatively similar characteristics to the characteristics of Avicel PH-101 as a comparison. ${ }^{2}$

In previous studies, cellulase tests were carried out on several types of mold isolates with Trichoderma reesei as a positive control. Based on the results of cellulase activity screening using DNSspectrophotometric reduction sugar method, the cellulase enzyme work from Trichoderma reesei has not been optimal. ${ }^{3}$ This is due to the very high activity of $\beta$-glucosidase. ${ }^{4}$ Cellulose enzyme performance can be improved by accepting $\beta$-glucosidase activity inhibitors from lichen.

In this study, the method of making MCC from water hyacinth was specifically carried out by giving inhibitors of $\beta$-glucosidase derived from lichens. The yield of MCC will be compared with MCC as results of enzymatic hydrolysis that are not given $\beta$-glucosidase inhibitors. MCC will be identified, characterized and compared to commercially available MCC (Avicel PH-101).

\section{MATERIALS AND METHODS}

\section{Sample and chemical materials}

Raw materials used in this study were water hyacinth powder obtained from Balai Tanaman Obat dan Rempah (BALITRO). Sources of lichen as potential $\beta$-glucosidase inhibitors were obtained from Curug Tilu Leuwi Opat, West Java. Trichoderma reesei as cellulase enzyme were obtained from IPB Culture Collection (IPBCC). Reagents used in this study were Dinitro Salicylic Acid (Sigma-Aldrich, USA) Other reagents and chemicals used in the study were technical.

\section{Cellulase enzyme extraction}

Extraction started with making spore suspension by adding sterile water into a test tube containing a culture stock of cellulolytic isolates. Then, it was scratched until the spores dissolved in the sterile water. A total of $10 \mathrm{~mL}$ of suspension of the spore and $10 \mathrm{~mL}$ of $0.1 \%$ of Tween 80 were fed into 200 $\mathrm{mL}$ of nutrient solution. Then stirred at $150 \mathrm{rpm}$ for $2 \mathrm{~h}$ at room temperature. A mixture of $30 \mathrm{~mL}$ was taken and centrifuged at $3000 \mathrm{rpm}$ for $10 \mathrm{~min}$. From centrifugation results obtained supernatant used as a rough enzyme for screening cellulase activity,

Cite this article: Putri $\mathrm{CB}$, Sutriyo, Suryadi $\mathrm{H}$. Effect of Beta Glucosidase Inhibitor from Lichen Extract in Microcrystalline Cellulose Preparation from Water Hyacinth (Eichhornia crassipes). Pharmacog J. 2019;11(6):1199-203. 
evaluation of $\beta$ - glucosidase inhibitors and enzymatic hydrolysis of cellulose into microcrystalline cellulose. ${ }^{2}$

\section{$\beta$-glucosidase inhibitor extraction and evaluation}

The lichens are rinsed to remove dirts, left at room temperature for 24 $h$ and cut into pieces. The lichens were extracted by maceration method using $1 \mathrm{~L}$ ethyl acetate solvent for $72 \mathrm{~h}$ with solvent replacement every $24 \mathrm{~h}$. Then, the extraction results are mixed together and evaporated at room temperature. Lichen extract was diluted in a concentration of $1000 \mathrm{ppm}$ using acetate buffer and concentration variations were made, namely $40 ; 60 ; 80 ; 100 ; 120$ and 140 ppm.

Evaluation of cellulase activity from Trichoderma reesei based on clear zones in CMC media was carried out by cellulose degradation test method. To know the effect of $\beta$-glucosidase inhibitors, $2.5 \mu \mathrm{L}$ of crude enzyme extract and $2.5 \mu \mathrm{L}$ of lichen extract with a concentration of 40 ppm were injected into a paper disk using a micropipette on a petri dish containing CMC, NaNO3, $\mathrm{KH} 2 \mathrm{PO} 4, \mathrm{KCl}, \mathrm{MgSO} 4.7 \mathrm{H} 2 \mathrm{O}$ media, yeast extract and glucose. The petri dishes are then incubated at $27-28^{\circ} \mathrm{C}$ for 3-7 days. For comparison, the media with enzyme extracts were tested without the addition of lichens extract. The clear zone formed around the paper disc shows cellulolytic activity.

\section{Preparation of a-cellulose isolation}

A total of $300 \mathrm{~g}$ of sifted water hyacinth powder then placed in a beaker glass was added with $4 \mathrm{~L}$ of $3.5 \%$ nitric acid (containing $40 \mathrm{mg}$ sodium nitrite) and heated for $2 \mathrm{~h}$ at $90^{\circ} \mathrm{C}$ above the waterbath. After that, the residue is filtered and washed with water. The residue is then immersed in $3 \mathrm{~L}$ of a solution containing Sodium Hydroxide and Sodium Sulfite each $2 \% \mathrm{w} / \mathrm{v}$ and heated at $50^{\circ} \mathrm{C}$. for $1 \mathrm{~h}$. Then the residue is filtrated and washed with water. Bleaching with $2 \mathrm{~L}$ of water solution with $3.5 \%$ Sodium Hypochlorite 1: 1 and boiled for $10 \mathrm{~min}$ followed by filtration and washing of residues using water. The obtained residue was added $17.5 \% \mathrm{w} / \mathrm{v} \mathrm{NaOH}$ then heated for $30 \mathrm{~min}$ at $80^{\circ} \mathrm{C}$., after which it was filtrated and washed again with water. The resulting residue is a-Cellulose. The extraction was continued by mixing $\alpha$-Cellulose in 2 $\mathrm{L}$ water mixture and 3.5\% 1: 1 Sodium Hypochlorite which was heated at $100^{\circ} \mathrm{C}$ for $5 \mathrm{~min}$. The residue is filtered and washed thoroughly. Then dried in an oven with a temperature of $60^{\circ} \mathrm{C}$ and obtained $\alpha$-cellulose powder. $^{5}$

\section{Method of cellulite enzyme microcrystalline cellulose preparation by hydrolysis}

The $10 \mathrm{~g}$ a-Cellulose was hydrolyzed enzymatically with $0.05 \mathrm{M}$ Sodium Acetate buffer $\mathrm{pH} 7$ of $100 \mathrm{~mL}$ while adding a mixture of cellulase enzyme with $5 \mathrm{~mL}$ inhibitor at $30^{\circ} \mathrm{C}$ and $160 \mathrm{rpm}$ for $2 \mathrm{~h}$ above water-shaking incubator. Thereafter, the mixture was centrifuged at $5,500 \mathrm{rpm}$ (at a temperature of $7-10^{\circ} \mathrm{C}$ for $30 \mathrm{~min}$ ). The rest of the enzyme was removed by washing residue that settled with the aquades then dried.

\section{Identification and characterization}

The identification was performed using FTIR (Shimadzu FTIR-8400s) to determine the functional groups present in microcrystalline cellulose samples compared to the Avicel PH 101 standard.

\section{Scanning electron microscope (SEM)}

The sample was inserted into a room then irradiated with a $10 \mathrm{kV}$ electron beam so that the sample ejected detectable secondary electrons, detonating electrons and a detector scientor, which was then reinforced with an electrical circuit causing a CRT (Catode Ray Tube) image. Shooting was done after selecting a certain part of the object (sample) and magnification was desired so that obtained a good and clear photograph. Identification was compared to Avicel PH 101.

\section{X-Ray diffractometer (XRD)}

The sample was printed on a circular plate mold and flattened until no wave is formed on the sample surface. Measurements were made using XRD Bruker D8 Advance ECO Diffractometer operated in reflection method $(40 \mathrm{kV}, 35 \mathrm{~mA})$ using $\mathrm{Cu}-\mathrm{Ka}$ radiation $(11=1,54060 \AA$ and 12 $=1,54439 \AA)$ and using step scan method with initial position $\left({ }^{\circ} 20\right)$ of $5,000^{\circ}$, step size $\left({ }^{\circ} 20\right)$ of $0.020^{\circ}\left(76.8 \mathrm{~s}\right.$ per step) and ending at $\left({ }^{\circ} 20\right)$ of $80.009^{\circ}$. The resulting diffraction pattern was compared to Avicel $\mathrm{PH}$ 101.

\section{Particle size and distribution analysis}

Preparation was done by dispersing the crystal powder in an appropriate medium which can disperse the sample powder. In this test, ethanol dispersion medium was used. Requirements for particle size distribution testing ranged from $0.01-200 \mu \mathrm{m}$.

\section{$\mathrm{pH}$ test, ash content and starch test}

The method used in this test is based on the Farmakope Indonesia $2014 .^{6}$

\section{Water content and organoleptic}

Moisture content was measured using moisture content (Adam) with a temperature of $105^{\circ} \mathrm{C}$. A number of samples were weighed $\pm 1.0 \mathrm{~g}$ on the aluminum plate that had been previously held. Then the appliance is turned on and the tool will measure the water content of the sample. The experiment is repeated using the Avicel PH 101 standard. A good microcrystalline cellulose powder is a white, odorless and tasteless powder.

\section{Particle density}

The density test of powder particles is done by bulk-tapped density. First, the product produced is weighed to meet $\pm 60 \%$ of the $50 \mathrm{~m}$ polygonal-grounded measuring cup, then the volume is recorded (bulk volume / Vb). Next, the polygonal grounded measuring cylinder is placed on the tool. Then, the tool is turned on and set to 250 beats / $\mathrm{min}$, then recorded the final volume (tapped density / Vt). The experiment was repeated using the Avicel PH 101.

\section{Flow rate test}

Microcrystalline cellulose powder weighed approximately $10 \mathrm{~g}$. The powder is fully inserted into the flowmeter. Flowmeter switched on, calculate the time required until all the powders flow down recorded and then calculate the flow rate. The experiment was repeated and compared using Avicel PH 101 powder.

\section{Angle of repose test}

Microcrystalline cellulose powder weighed approximately $10 \mathrm{~g}$. The powder is carefully poured into the flowmeter funnel until the end of the powder conical touches the end of the funnel. Then the end cover of the funnel is opened slowly so that the powder flows down slowly.

\section{Loss on drying test}

A total of $1 \mathrm{~g}$ of sample was included in porcelain crucible, then dried in an oven at $105^{\circ} \mathrm{C}$ for $3 \mathrm{~h}$ until constant weight was obtained.

\section{RESULTS}

\section{Cellulase enzyme extraction}

Cellulase enzyme extraction was performed by dissolving $10 \mathrm{~mL}$ of spore suspension and $10 \mathrm{~mL}$ of Tween $800.1 \%$ into nutrient solution. The addition of tween $800.1 \%$ was done to increase the permeability of the cells so that the enzyme is easier to get out of the cell wall. From the 
centrifugation results obtained a supernatant crude cellulase enzyme in which the pellets are formed like thin of thread. The supernatant obtained was then used for evaluation of the action of $\beta$ - glucosidase inhibitor, quantitative screening, optimization for enzymatic hydrolysis and enzymatic hydrolysis of cellulose microcrystalline.

\section{Evaluation of $\beta$-glucosidase inhibitors}

Screening results using Spectrophotometer UV-Vis show that increasing the concentration of lichens extract has the effect of decreasing glucose concentration. Based on these results, the extract of lichens with $120 \mathrm{ppm}$ concentration was used to optimize hydrolysis conditions and $a$-cellulose enzymatic hydrolysis. This concentration is considered optimum because the lowest glucose concentration produced. In addition, differences in glucose levels produced at $120 \mathrm{ppm}$ and $140 \mathrm{ppm}$ extracts of crusty moss extract were not significant.

\section{Preparation of a - cellulose from water hyacinth (Eicchornia crassipes)}

The results obtained from the preliminary process are then weighed and crushed to a fine powder. But in the process, found some difficulties that is difficult to clean the powder because the original color of dark green dust so the color of the powder of the insulation results are less white, while the expected color is white. In addition to the washing process, this can occur due to lack of perfect in the process of delignification. After being isolated the dried powder is very difficult to crushed or blended, so the resulting powder is not smooth. The result of a-cellulose isolation obtained from $600 \mathrm{~g}$ of water hyacinth powder was $87.8 \mathrm{~g}(14.63 \%)$.

Making microcrystalline cellulose with enzymatic hydrolysis method by cellulase enzyme and $\beta$ glucosidase inhibitor

Manufacture of microcrystalline cellulose by enzymatic hydrolysis method of cellulase enzyme with addition of inhibitor compared with enzymatic hydrolysis of cellulase enzyme without addition of inhibitor. When compared, without addition of inhibitor showed 63\% yield and a little higher yield (70\%) was obtained with the addition of inhibitor (data not shown).

\section{Identification using FTIR}

Based on the literature (Azubuike and Okhamafe, 2012), the main peaks in the infrared spectrum of microcrystalline cellulose are among $3500-3300 \mathrm{~cm}^{-1}(\mathrm{OH}), 2900-2800 \mathrm{~cm}^{-1}$ (CH aliphatic), $1650 \mathrm{~cm}^{-1}(-\mathrm{O})$ - drag the neighboring hydrogen atom), $900 \mathrm{~cm}^{-1}$ ( $\beta$-glycosidic bond) and $1060 \mathrm{~cm}^{-1}(\mathrm{C}-\mathrm{OH}) .^{8}$

\section{Scanning electron microscope (SEM)}

SEM test results showed the formation of microcrystals in microcrystalline cellulose samples. At 500x magnification, it can be seen that microcrystalline cellulose samples have similar morphology with Avicel PH-101 standard.

\section{Analysis of X-Ray diffractometer (XRD)}

Avicel PH-101 standard diffractogram shows two peaks. Sharp peaks at $2 \theta 22.71$ indicate the presence of crystalline polymers and the peak widened at $2 \theta 18.77$ indicates the presence of amorphous polymers in the standard. Sharp peaks in microcrystalline cellulose samples at $2 \theta 20.17$ and 21.89 show the crystalline part of the sample. The peak widened at 2018.10 indicating the presence of amorphous parts in the sample. The peak doublet that appears on the crystalline part of the sample indicates the change from polymorph cellulose I to polymorphic cellulose II which can be caused by exposure between the powder that has been bleached with $17.5 \%(\mathrm{w} / \mathrm{v})$ sodium hydroxide solution when isolating $\alpha$-cellulose. The discovery of doublet peaks in the crystalline part also occurs in microcrystalline cellulose produced from oil palm fibers (Xiang, Mohammed and Baharuddin, 2016) and corncob (Azubuike and Okhamafe, 2012) ${ }^{8,9}$ Based on the results of the diffractogram, the standard crystallinity (CI) and sample index values were known, ie $67.11 \%$ for Avicel-PH 101 standard and $79.08 \%$ for microcrystalline cellulose samples (Table 1).

\section{Characterization}

As seen in Table 2. (Figures 1-3 and Table 3).

\section{DISCUSSION}

The $\beta$-glucosidase inhibitor was extracted from lichen with maceration method with ethyl acetate as solvent. The process took $72 \mathrm{~h}$ with solvent changing every $24 \mathrm{~h}$. The solvent then filtered and the filtrate was evaporated. The extract was made into six different concentration $(20,40,60,80,100,120,140 \mathrm{ppm})$ that were tested with DNS assay using spectrophotometer UV-Vis. The result showed that the lichen has $\beta$-glucosidase inhibitor activity and from six concentration, $120 \mathrm{ppm}$ concentration is chosen for the next process. The process continued with cellulase enzyme extraction

Table 1: Clear zones formed on the evaluation of $\beta$ - glucosidase inhibitors.

\begin{tabular}{ccc}
\hline $\begin{array}{c}\text { Lichen extract } \\
\text { concentration }\end{array}$ & $\begin{array}{c}\text { Absorbance } \\
(\mathrm{A})\end{array}$ & $\begin{array}{c}\text { Glucose } \\
\text { concentration }(\mathrm{ppm})\end{array}$ \\
\hline Without lichen extract & 0.32708 & 79.38 \\
$40 \mathrm{ppm}$ & 0.27366 & 73.02 \\
$60 \mathrm{ppm}$ & 0.26419 & 71.89 \\
$80 \mathrm{ppm}$ & 0.25928 & 71.31 \\
$100 \mathrm{ppm}$ & 0.21665 & 66.23 \\
$120 \mathrm{ppm}$ & 0.12008 & 54.74 \\
$140 \mathrm{ppm}$ & 0.11575 & 54.22 \\
\hline
\end{tabular}

Table 2: Results of characterization of microcrystalline cellulose samples from hydrolysis.

\begin{tabular}{ccc}
\hline Test & Requirement & Sample \\
\hline Organoleptic & No color, tastes, and odor & $\begin{array}{c}\text { Yellowish color, with no } \\
\text { tastes and odor }\end{array}$ \\
Starch & No color & No color \\
$\mathrm{pH}$ & $\mathrm{pH} \leq 5.0$ dan $\mathrm{pH} \geq 7.5$ & $\mathrm{pH} 7.03$ \\
Loss on drying & $\leq 7.0 \%$ & $3.16 \%$ \\
Ash content & $\leq 0.1 \%$ & $0.23 \%$ \\
Moisture content & $\leq 5 \%$ & $3.42 \%$ \\
Particle size & $20-200 \mu \mathrm{m}$ & $15.46 \mu \mathrm{m}$ \\
& & BD: $0.75 \mathrm{~g} / \mathrm{cm}^{3}$ \\
Particle density & $\mathrm{BD}: 0.25-0.50 \mathrm{~g} / \mathrm{cm}^{3}$ & TD: $0.73 \mathrm{~g} / \mathrm{cm}^{3}$ \\
& $\mathrm{TD}: 0.33-0.70 \mathrm{~g} / \mathrm{cm}^{3}$ & Carr's: $21.23 \%$ \\
Flow rate & $\leq 1.41 \mathrm{~g} / \mathrm{s}$ & Hausner: 1.27 \\
Angle of Repose & $34.4-49^{\circ}$ & $1.43 \mathrm{~g} / \mathrm{s}$ \\
\hline
\end{tabular}

Table 3: Pharmacokinetic parameters of oral insulin nanoparticles.

\begin{tabular}{ccc}
\hline Parameter & Test group & Positive control \\
\hline $\mathrm{C}_{\max }(\mathrm{pg} / \mathrm{ml})$ & 1325.83 & 2301.67 \\
$\mathrm{~T}_{\max }($ minutes $)$ & 120 & 60 \\
$\mathrm{AUC}_{0-\mathrm{t}}(\mu \mathrm{g} \cdot$ hour $/ \mathrm{ml})$ & 0.30 & 0.32 \\
$\mathrm{~K}_{\mathrm{a}}\left(\right.$ hour $\left.^{-1}\right)$ & 0.15 & 0.18 \\
$\mathrm{~K}_{\mathrm{e}}\left(\right.$ hour $\left.^{-1}\right)$ & 0.08 & 0.20 \\
$\mathrm{t}_{1 / 2}$ (hour $)$ & 8.22 & 3.38 \\
\hline
\end{tabular}




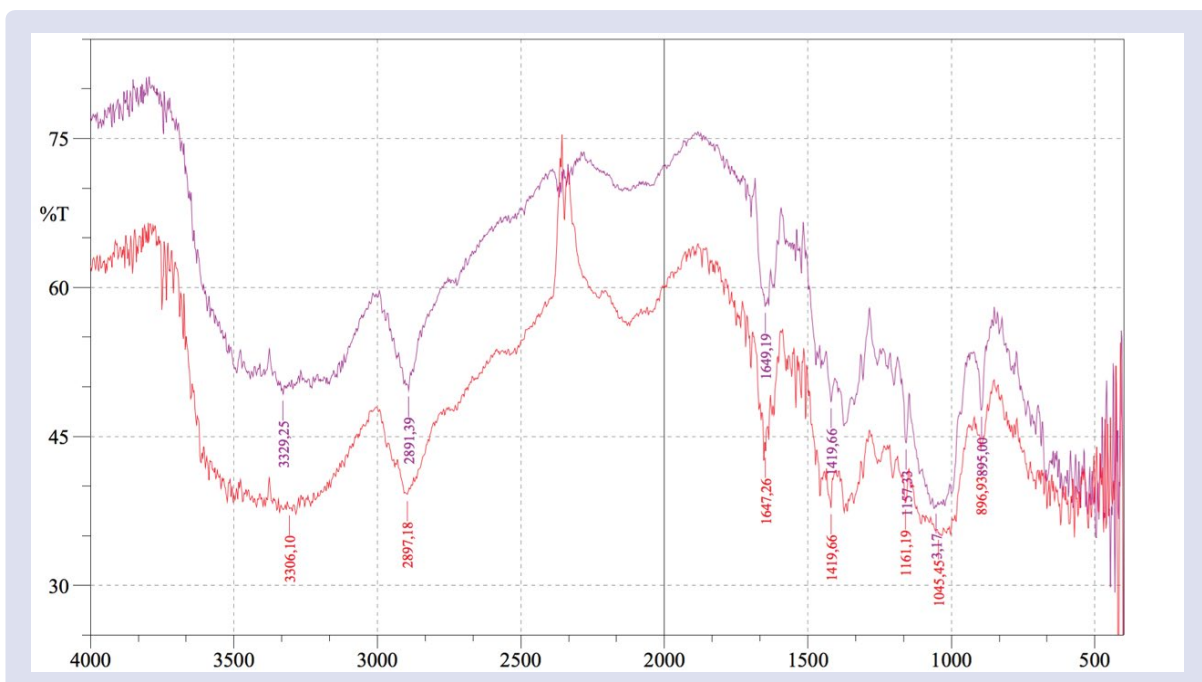

Figure 1: The identification results using a standard FTIR Avicel PH 101 (red) and microcrystalline cellulose powder samples of hydrolysis (purple).
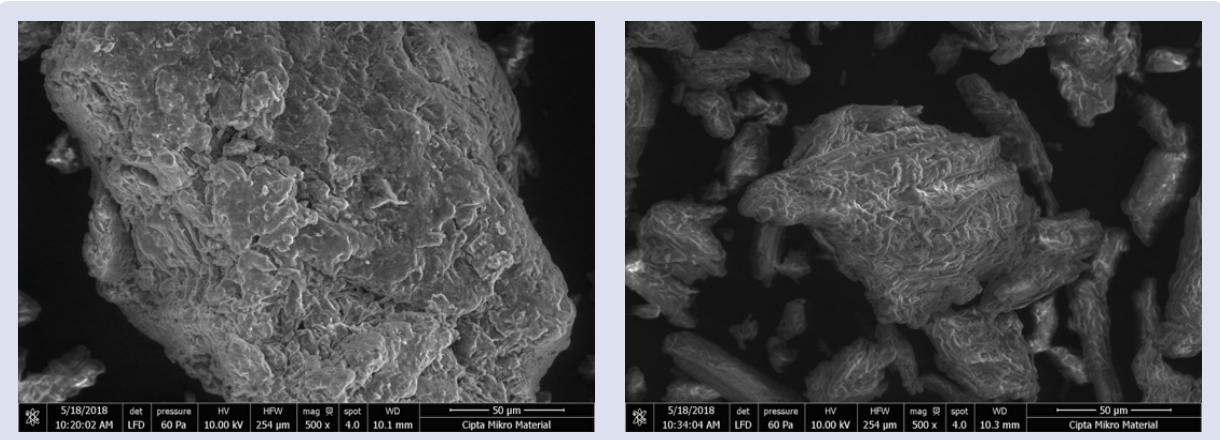

Figure 2: Results of SEM analysis on (a) Avicel PH-101 and (b) microcrystalline cellulose powder samples from water hyacinth with magnification of 500x.

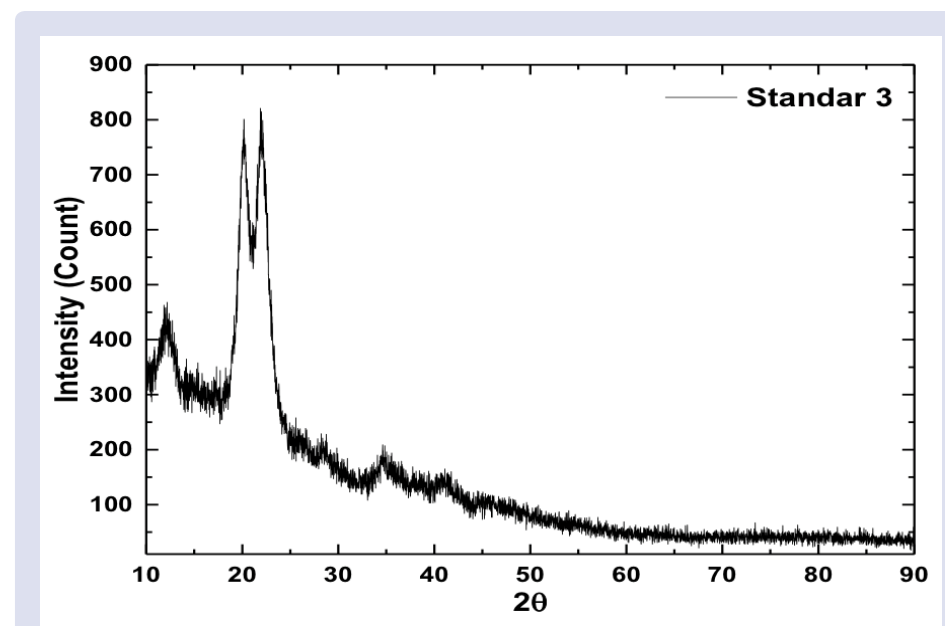

Figure 3: Diffractogram of microcrystalline cellulose from water hyacinth .

from Trichoderma reesei. Optimization of enzymatic hydrolysis process was conducted with testing of sample, cellulase enzyme and inhibitor, with the results that duration of hydrolysis of $4 \mathrm{~h}$ in acetate buffer solution $\mathrm{pH} 7$ in $28^{\circ} \mathrm{C}$ could produce the lowest glucose concentration.

Manufacture of MCC by enzymatic hydrolysis method with inhibitor was compared with enzymatic hydrolysis without inhibitor, with results that yield of enzymatic hydrolysis method with inhibitor was higher than without inhibitor. Characterization of MCC samples showed that organoleptic test, starch test, moisture content, acidity degree, drying rate and flow rate test has met the existing requirement. But for ash level test, the test results do not meet the requirements because there are still a lot of residues of inorganic compounds derived from plants water hyacinth. For particle density test and angle 
of repose, the results of microcrystalline cellulose powder samples fall into the excellent category.

\section{CONCLUSION}

The extract of potential lichens has $\beta$-glucosidase inhibitor properties and can increase the yield of $\alpha$-cellulose enzymatic hydrolysis by up to $7 \%$. The optimum condition of cellulase enzyme hydrolysis by extracting lichen $\beta$-glucosidase inhibitors using $\alpha$-cellulose substrate from water hyacinth is at $\mathrm{pH} 7$ and duration of $4 \mathrm{~h}$.

The results of identification with FTIR showed similarities between microcrystalline cellulose from water hyacinth with standard; organoleptic cellulose microcrystalline from water hyacinth is similar to the standard but more yellowish in color; analysis with SEM shows the existence of morphological equations; analysis with XRD shows a crystallinity index of $67.11 \%$; PSA analysis showed particle size diameter of $2.01 \mu \mathrm{m}$; qualitative analysis, acidity level, starch test, moisture content, drying shrinkage test meet the requirements; ash content does not meet the requirements; particle density test, flow rate test and break angle test meet the requirements.

\section{ACKNOWLEDMENT}

The authors want to acknowledge DRPM UI for grant of Hibah PITTA to our study.

\section{REFERENCES}

1. Abdel-Fattah AF, Abdel-Naby MA. Pretreatment and enzymatic saccharification of water hyacinth cellulose. Carbohydr Polym. 2011;2109-13.

2. Suryadi H, Sutriyo, Sari HR, Rosikhoh D. Preparation of microcrystalline cellulose from water hyacinth powder by enzymatic hydrolysis using cellulase of local isolate. J Young Pharm. 2017;19-23.

3. Murti MW Isolasi Kapang Penghasil Enzim Selulase dan Pemanfaatan Aktivitas Selulasenya untuk Preparasi Selulosa Mikrokristal dari Eceng Gondok (Eichhornia crassipes). [Skripsi]. Depok: Universitas Indonesia; 2017.

4. Tsai CT, Meyer AS. Enzymatic cellulose hydrolysis: Enzym reusability and visualization of $\beta$-glucasidase immobilized in calcium alginate. Molecules. 2014;19390-406.

5. Ohwoavworhua F, Adelakun T, Okhamafe A. Processing pharmaceutical grade microcrystalline cellulose from groundnut husk: Extraction methods and characterization. International Journal of Green Pharmacy. 2009;3(2):97.

6. Ministry of Health Republic of Indonesia. Farmakope Indonesia Edisi V Jakarta: Direktorat Jenderal Bina Kefarmasian dan Alat Kesehatan Kementerian Kesehatan RI; 2014.

7. United States Pharmacopeial Convention. The United States Pharmacopeia: The National Formulary (31th ed.). Maryland: United States Pharmacopeia Convention; 2013.

8. Azubuike $\mathrm{CP}$, Okhamafe AO. Physicochemical, spectroscopic and therma properties of microcrystalline cellulose derived from corncobs. Journal of Recyling of Organic Waste in Agriculture. 2012;1(9):1-7.

9. Xiang LY, Mohammed MA, Baharuddin AS. Characterisation of microcrystalline cellulose from oil palm fibres for food applications. Carbohydr Polym. 2016;11-20.

Cite this article: Putri CB, Sutriyo, Suryadi H. Effect of Beta Glucosidase Inhibitor from Lichen Extract in Microcrystalline Cellulose Preparation from Water Hyacinth (Eichhornia crassipes). Pharmacog J. 2019;11(6):1199-203. 